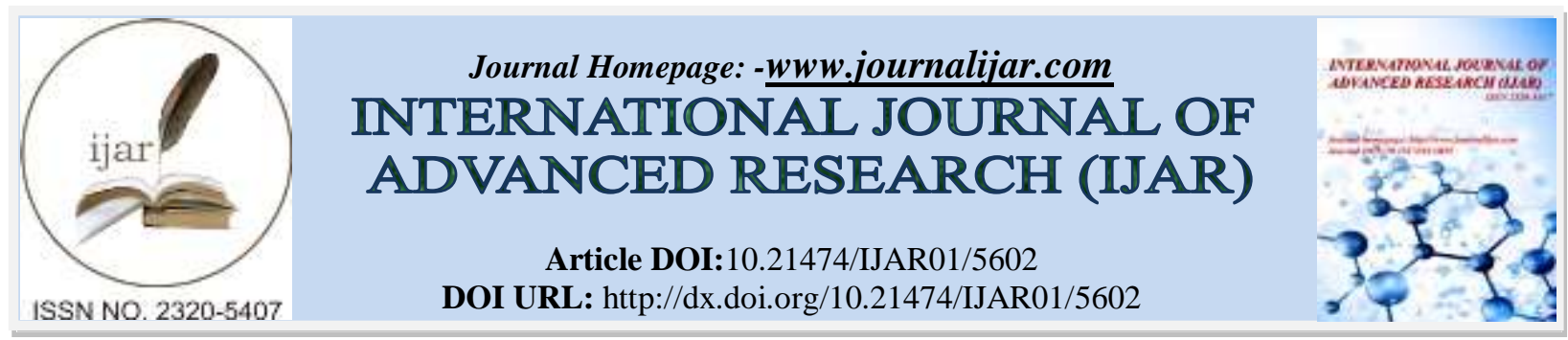

RESEARCH ARTICLE

\title{
CHEMICAL CHARACTERISTICS OF FRUIT LEATHER MIXTURE OF KOLANG KALING (Arenga pinnata) AND JACKFRUIT (Artocarpus heterophyllus).
}

Rina Yenrina, Tuty Anggraini and Zedra Maulana.

Faculty of Agricultural Technology, Andalas University Padang 25163, Indonesia

\section{Manuscript Info}

Manuscript History

Received: 12 August 2017

Final Accepted: 14 September 2017

Published: October 2017

Key words:-

Chemical Characteristics, Fruit Leather, JackFruit, Kolang Kaling.

\section{Abstract}

This research was aimed to determine chemical characteristics of fruit leather mixture of sugar palm fruit (Arenga pinnata) with jackfruit (Artocarpus heterophyllus). This research used a completely randomized design (CRD) with 5 treatments and 3 replications. Data were analyzed statistically using ANOVA continued by Duncan's New Multiple Range Test (DNMRT) at 5\% level. The treatment of this research was a mixture of kolang kaling and jackfruit of $90 \%: 10 \%$, $80 \%: 20 \%, 70 \%: 30 \%, 60 \%: 40,50 \%: 50 \%$. The observed parameters in this research was the water content, ash content, betacarotene content and antioxidant activity. The result of this research showed that mixture of kolang kaling and jackfruit significantly influenced the water content and ash content but not significant in betacarotene content and antioxidant activity.

Copy Right, IJAR, 2017,. All rights reserved.

\section{Introduction:-}

Fruit is a perishable commodity and some times the amount of its very abundant, especially during the harvest season. In these conditions, the fruit provided in excess so that it is necessary to find an alternative for the utilization. One such alternative is to make the fruit as processed products. The aim of this treatment is to extending the shelf life, as well as to improve the taste more delicious and high economic value. Fruits are generally made into refined products such as jam, jelly, fruit juice, canned fruit, dry or wet candied. One type of dried product beside the dry candy is fruit leather.

Fruit leather is a thin sheet food product. The taste of fruit leather according to the fruit used. Fruit leather is a kind of candied dried to be used as a form of commercially processed on an industrial scale with a very easy way, that crushed fruits into a puree and dried it (Raab and Oehler, 2000) ${ }^{\mathbf{1}}$.

No Fruit leather quality standard yet, but the good fruit leather has a moisture content of 10-25\%, Aw values of less than 0.7, such as skin texture plastic appearance, looks shiny, it can be consumed directly (Nurlaely, 2002) ${ }^{2}$. According to Winarti $(2008)^{\mathbf{3}}$, in the presence or absence of binder material in making fruit leather can affect the quality of fruit leather produced, especially the texture and appearance. Binder that can be used is seaweed carrageenan, agar-agar, alginate, tapioca, corn starch wheat, Maltodextrin and gelatin.

In Indonesia, fruit leather is still not produced commercially. Although the process of making it is not so difficult, but the fruit leather is not widely known by people. Fruit and vegetable leather can be made from vegetable material that serves as a source of nutrients that can be classified as functional food. In the making of fruit leather materials 
used are fruit, sugar, and the structure-forming agent of fruit leather, such as agar, seaweed, kolang kaling and others.

In this study the structure-forming agent that used was kolang kaling, kolang kaling had a quite high of fiber content. In 100 grams kolang kaling contained about 1.6 grams of fiber (Ratima, 2014) ${ }^{4}$. Gel formation is influenced by three components, namely the formation of a gel material (pectin), sugar and acidity. Gelling is the result of the formation of hydrogen between pectin molecules so that the resulting semi-solid gel-bound along the water. Pectin will clot and form fine fibers, this structure is able to withstand the liquid so that it will form a solid gel. One of the gels forming material is kolang kaling, because it contains pectin in high quantities (Ipi, 2014) ${ }^{\mathbf{5}}$.

Kooiman (1971) ${ }^{6}$ also said, dietary fiber in kolang kaling is a class of carbohydrates group of galactomannan as a hydrocolloid. According to Fardiaz $(1989)^{7}$, hydrocolloid is a water-soluble polymer, has the ability to thicken or form the aqueous gel system. Hydrocolloid compound built by a polysaccharide compounds that produce the gel can be used as an adhesive (Anggadiredja, Zatnika, Purwoto and Istini, 2006) ${ }^{\mathbf{8}}$. Thus kolang kaling potentially develop as a raw material in the making of fruit leather, for according to Winarti (2008) ${ }^{\mathbf{3}}$, in the making of fruit leather where the adhesive or binder greatly affect the quality of fruit leather that produced, especially the texture and appearance. Kolang kaling is a material without a strong flavor with a white translucent color. Therefore in need of adding color and flavor. Jackfruit is a fruit that has a strong flavor and aroma and can be mixed with kolang kaling in the making of fruit leather but it also can add nutrients of fruit leather. So we get the fruit leather with tasty flavors and colored with better nutrients content.

Jackfruit (Artocarpus heterophyllus) is a tropical fruit species that are multi functional and can be grown in tropical regions that originated from South India. The characteristics of the ripe jackfruit which has a large of spines and rarely, have the aroma and strong taste, after picking fresh yellow flesh, not many contain latex. The fruit can be eaten immediately or processed into a variety of cuisines (Widyastuti, 1993) ${ }^{\mathbf{9}}$. The treatment used in this study based on prestudy that has done by the author. Based on the explanation above, author did a research on the chemical characteristics of fruit leather mixture of kolang kaling (Arenga pinnata) and jackfruit (Artocarpus heterophyllus)

\section{Methodology:-}

This research was conducted in Laboratory of Process Engineering Technology, and Laboratory of Chemistry, Biochemistry and Nutrition of Department of Agricultural Product Technology, Faculty of Agricultural Technology. Andalas University.

\section{Materials and Tools:-}

Raw material for making fruit leather that is used in this study was kolang kaling that ready to use, jackfruit pulp, sugar, and water. The chemicals used are $20 \% \mathrm{NaOH}, 0.5 \mathrm{~N} \mathrm{HCl}, \mathrm{H}_{2} \mathrm{SO}_{4} 1.25 \%, \mathrm{Na}_{2} \mathrm{~S}_{2} \mathrm{O}_{3}, 1.25 \% \mathrm{NaOH}_{2} \mathrm{H}_{2} \mathrm{SO}_{4}$ $26.5 \%, 99.8 \%$ Ethanol, methanol, DPPH solution, as well as other chemicals that are used for analysis.

Tool used were oven, blender, stove, hot plate, an analytical balance, knives, bowls clamp, desiccator, burette, cup aluminum, furnaces, pipette, porcelain dish, erlenmeyer, Buchner funnel, and other tools.

\section{Research Design:-}

This study was designed using completely randomized design (CRD) with 5 treatments and 3 replications.Data were analyzed statistically using ANOVA continued by Duncan's New Multiple Range Test (DNMRT) at 5\% level. The treatment used was the different percentage of kolang kaling and jackfruit of 100 grams raw materials. Based on the total raw materials:

$\mathrm{A}=90 \%$ kolangkaling : $10 \%$ jackfruit

$\mathrm{B}=80 \%$ kolang kaling : $20 \%$ jackfruit

$\mathrm{C}=70 \%$ kolang kaling : $30 \%$ jackfruit

$\mathrm{D}=60 \%$ kolang kaling : $40 \%$ jackfruit

$\mathrm{E}=50 \%$ kolang kaling : $50 \%$ jackfruit 
Table 1:- Formulation of Fruit Leather Mixture of Kolang Kaling and Jackfruit *

\begin{tabular}{|l|c|c|c|c|c|}
\hline \multirow{2}{*}{ Ingredients } & \multicolumn{5}{|c|}{ Treatments } \\
\cline { 2 - 6 } & A & B & C & D & E \\
\hline Kolang kaling $(\mathrm{g})^{\mathrm{a}}$ & 90 & 80 & 70 & 60 & 50 \\
\hline Jackfruit (g) ${ }^{\mathrm{b}}$ & 10 & 20 & 30 & 40 & 50 \\
\hline Sugar $(\mathrm{g})$ & 20 & 20 & 20 & 20 & 20 \\
\hline Water (ml) & 100 & 100 & 100 & 100 & 100 \\
\hline
\end{tabular}

Description : a and b was total ingredients made basic 100 grams of fruit leather raw materials

*(Yenrina, 2015) ${ }^{\mathbf{1 0}}$ Methods with modification

\section{Implementation:-}

Preparation of Materials:-

Kolang kaling purchased at Pasar Raya Padang. Soaked overnight in water, then washed. Jackfruit prepared, which was purchased in Pasar Raya Padang. Washed and cut into pieces.

\section{Process:-}

Fruit Leather (Yenrina, 2015) ${ }^{10}$ methods with modification:-

Raw materials are weighed according to the formula that has been set. Added kolang kaling, jackfruit, sugar, and water into a blender, then blend until smooth. After completion of blended ingredients cooked briefly about 1 minute with a temperature of $40^{\circ} \mathrm{C}$. Then the materials flattened over the pan with a thickness of approximately 2-3 mm. Then put a pan in the oven, at $50^{\circ} \mathrm{C}$ for 24 hours. Took the fruit leather from pan and packed used aluminium foil and put in a jar, fruit leather ready for further analysis.

\section{Observation:-}

Analysis was done to fruit leather that produced. Analysis of chemical properties: water content, ash content, (Yenrina, et al., 2011) ${ }^{\mathbf{1 1}}$ beta carotene (Nielsen, 1995) ${ }^{\mathbf{1 2}}$ antioxidant activity (Huang, et al., 2005) ${ }^{\mathbf{1 3}}$

\section{Results And Discussion:-}

Table 2:- Water content of fruit leather Mixture of Kolang Kaling and Jackfruit

\begin{tabular}{|l|l|}
\hline Treatments & \multicolumn{1}{|c|}{ Water Content (\% \pm SD) } \\
\hline A $(90 \%$ KK $: \mathrm{J} 10 \%)$ & $12.33 \pm 0.80 \mathrm{a}$ \\
\hline $\mathrm{B}(80 \% \mathrm{KK}: \mathrm{J} 20 \%)$ & $12.89 \pm 0.25 \mathrm{a} \mathrm{b}$ \\
\hline $\mathrm{C}(70 \% \mathrm{KK}: \mathrm{J} 30 \%)$ & $14.29 \pm 0.40 \quad \mathrm{~b} \mathrm{c}$ \\
\hline $\mathrm{D}(60 \% \mathrm{KK}: \mathrm{J} 40 \%)$ & $15.66 \pm 0.61 \quad \mathrm{c}$ \\
\hline $\mathrm{E}(50 \% \mathrm{KK}: \mathrm{J} 50 \%)$ & $19.21 \pm 1.39 \quad \mathrm{~d}$ \\
\hline CV $=10.44$ & \\
\hline
\end{tabular}

$\mathrm{KK}=$ Kolang Kaling. J= Jackfruit

Description: The figures in the same column followed by the same lowercase letters are not significantly different at the level of 5\% Duncan's New Multiple Range Test (DNMRT).

Table 3:- Ash Content of Fruit Leather Mixture of Kolang Kaling and Jackfruit

\begin{tabular}{|c|c|}
\hline Treatments & Ash Content $(\% \pm \mathrm{SD})$ \\
\hline A ( $90 \%$ KK : J 10\%) & $0.61 \pm 0.52 \mathrm{a}$ \\
\hline B (80\% KK : J 20\%) & $0.71 \pm 0.07 \quad b$ \\
\hline $\mathrm{C}(70 \% \mathrm{KK}: \mathrm{J} 30 \%)$ & $0.80 \pm 0.40$ \\
\hline $\mathrm{D}(60 \% \mathrm{KK}: \mathrm{J} 40 \%)$ & $0.84 \pm 0.33$ \\
\hline $\mathrm{E}(50 \% \mathrm{KK}: \mathrm{J} 50 \%)$ & $1.06 \pm 0.05$ \\
\hline $\mathrm{CV}=5.31$ & \\
\hline
\end{tabular}

$\mathrm{KK}=$ Kolang Kaling. J= Jackfruit

Description: The figures in the same column followed by the same lowercase letters are not significantly different at the level of 5\% Duncan's New Multiple Range Test (DNMRT). 
Table 4:-Betacarotene Content of Fruit Leather Mixture of Kolang Kaling and Jackfruit

\begin{tabular}{|l|c|}
\hline \multicolumn{1}{|c|}{ Treatments } & Betacarotene (mg/100g \pm SD) \\
\hline $\mathrm{A}(90 \% \mathrm{KK}: \mathrm{J} 10 \%)$ & $980.33 \pm 1.23$ \\
\hline $\mathrm{B}(80 \% \mathrm{KK}: \mathrm{J} 20 \%)$ & $1161.67 \pm 1.43$ \\
\hline $\mathrm{C}(70 \% \mathrm{KK}: \mathrm{J} 30 \%)$ & $1224.00 \pm 1.26$ \\
\hline $\mathrm{D}(60 \% \mathrm{KK}: \mathrm{J} 40 \%)$ & $1428.00 \pm 2.98$ \\
\hline $\mathrm{E}(50 \% \mathrm{KK}: \mathrm{J} 50 \%)$ & $1623.50 \pm 4.32$ \\
\hline $\mathrm{CV}=3.45$ & \\
\hline
\end{tabular}

$\mathrm{KK}=$ KolangKaling. $\mathrm{J}=$ Jackfruit

Table 5:- Antioxidant Activity of Fruit Leather Mixture of Kolang Kaling and Jackfruit

\begin{tabular}{|l|c|}
\hline Treatments & Antioxidant Activity (\% \pm SD) \\
\hline A (KK 90\%: J 10\%) & $14.89 \pm 3.07$ \\
\hline B (KK80\%: J 20\%) & $17.21 \pm 3.02$ \\
\hline C (KK70\%: J 30\%) & $19.41 \pm 5.09$ \\
\hline D (KK60\%: : 40\%) & $21.44 \pm 2.16$ \\
\hline E (KK50\%: J 50\%) & $23.62 \pm 11.07$ \\
\hline CV $=6.74:$ \\
\hline
\end{tabular}

$\mathrm{KK}=$ Kolang Kaling. J= Jackfruit

\section{Water Content:-}

Water is an important component in food, since water may affect the appearance, texture, and taste of food $\left(\right.$ Winarno, 2004) ${ }^{\mathbf{1 4}}$. The value of water content of fruit leather mixture kolangkaling and jackfruit can be seen in Table 2.

Results of variance showed the water content of fruit leather from a mixture kolang kaling with jackfruit significantly different at 5\% level. In the table 2.can be seen that the value of water content increased, with increasing levels of jackfruit. This presumably due for jackfruit had a high moisture content in $100 \mathrm{~g}$ of $70 \%$ (DepKes RI, 2009) ${ }^{\mathbf{1 5}}$. While kolang kaling water content in $100 \mathrm{~g}$ of material that is $94 \%\left(\right.$ Ratima, 2014) ${ }^{\mathbf{4}}$. This due to the absorption of water by the water-soluble dietary fiber content contained in the materials used in the making of fruit leather, dietary fiber contained in the material served to gel fruit leather. Kooiman (1971) ${ }^{6}$ added that dietary fiber in kolang kaling is a class of carbohydrates group of galactomannan as a hydrocolloid. Jackfruit also contains a number of pectins that is hydrocolloid. According to Hui, (2006) ${ }^{\mathbf{1 6}}$, gel formation mechanisms, namely the incorporation or binding of polymer chains forming a continuous three-dimensional net. Furthermore, this net captured or immobilized water there in and form a strong and rigid structure.

From Table 2. known that the average water content was highest in treatment $\mathrm{E}$ of $19.21 \%$ (50\% kolang kaling : $50 \%$ jackfruit), and the lowest was in treatment A of $12.33 \%$ (90\% kolang kaling : 10\% jackfruit). There is no standard of quality for vegetable leather or fruit leather yet, because fruit leather or vegetable leather is not well known by the public. Nurlaely (2002) ${ }^{2}$ said good fruit leather has a moisture content of 10-15\%, Aw values of less than 0.7 , such as skin texture plastic appearance, looks shiny, it can be consumed directly.

\section{Ash Content:-}

Results of variance showed that the average value of ash content in the fruit leather mixture kolangkaling and jackfruit with the different concentration of jackfruit significantly different at the level of $\alpha=5 \%$. The results of the analysis of the ash content of fruit leather mixture kolang kaling and jackfruit ranged from $0.61-1.06 \%$. The value of ash content in the fruit leather mixture kolang kaling and jackfruit can be seen in Table 3 .

Judging from the data in Table 3 known that ash content was highest in treatment E (50\% kolang kaling: $50 \%$ jackfruit) of $1.06 \%$ and as the lowest one found in treatment A (90\% kolang kaling : 10\% jackfruit) of $0.61 \%$. The higher of jackfruit concentration, the ash content obtained also became higher. This was presumably due to the ash content of both raw materials. In $100 \mathrm{~g}$ of kolang kaling contained ash content $1.0 \mathrm{~g}$ (USDA,2009) ${ }^{17}$. In jackfruit containing ash content of $0.6 \%$ (Muchtadi, 1981) ${ }^{\mathbf{1 8}}$. 
Ash is a waste products an organic substance of combustion, ash content of food ingredients and composition depending on the type of material and the ashing process. About $96 \%$ of the foodstuffs consist of organic matter and water, the rest is an inorganic material in the form of a mineral called ash (Winarno, 2004) ${ }^{\mathbf{1 4}}$. According to DeMan $(1997)^{19}$, combustion is performed at a temperature of $600^{\circ} \mathrm{C}$ will destroy organic compounds and inorganic compounds left on the ash content of samples tested.

\section{Analysis of Betacarotene:-}

Beta-carotene is a group of pigments in vegetables and fruits that are yellow, orange, red, fat soluble. Results of analysis of variance of the beta-carotene in fruit leather mixture kolang kaling and jackfruit were not significantly different at $5 \%$ level. The level of beta-carotene in fruit leather mixture kolang kaling and jackfruit can be seen in Table 4.

From Table 4. can be seen the level of betacarotene in fruit leather mixture kolang kaling and jackfruit ranged from 980.33 to $1623.5 \mathrm{mg} / 100 \mathrm{~g}$, the highest level of beta-carotene found in treatment $\mathrm{E}$ of $1623.5 \mathrm{mg} / 100 \mathrm{~g}(50 \% \mathrm{kolang}$ kaling : 50\% jackfruit), and the lowest level of beta-carotene found in treatment A (90\% kolang kaling: $10 \%$ jackfruit) of $980.33 \mathrm{mg} / 100 \mathrm{~g}$.

This study used jackfruit as raw material that suspected to contain betacarotene. Beta-carotene is one of a group of compounds called carotene. Carotene classes of compounds include alpha-carotene, zeaxanthin, lutein, and lycopene. In the body, these compounds will be converted into vitamin A. (Afrianti, 2010) ${ }^{\mathbf{2 0}}$. Source of carotene are dark green vegetables and fruits that are yellow-orange, such as cassava leaves, beans spinach, beans, chickpeas carrots, tomatoes, corn, mature jackfruit and orange (Almatsier, 2009$)^{\mathbf{2 1}}$. Vegetables and fruits that are green or yellow usually contain a lot of carotenes (Winarno, 2004) ${ }^{\mathbf{1 4}}$. Beta-carotene is a provitamin A and one type of carotenoid found in many fruits that are green or yellow (Astawan, 2009) ${ }^{\mathbf{2 2}}$. Betacarotene has antioxidant benefits that maintain health and prevent aging process, besides beta-carotene may prevent and suppress the growth of cancer cells and protects polyunsaturated fatty acids from oxidation (Sayuti and Yenrina. 2015) ${ }^{\mathbf{2 3}}$.

\section{Antioxidant Activity Analysis:-}

Based on analysis showed that the value of antioxidant activity in fruit leather mixture kolangkaling and jackfruit with the different concentration of jackfruit was not significant at the significance level $\alpha=5 \%$. The average value of the antioxidant activity of fruit leather mixture kolang kaling and jackfruit can be seen in Table 5 .

From Table 5. known that antioxidant activity of fruit leather mixture kolang kaling and jackfruit ranged from 14.89-23.62\% that measured at concentration of $1000 \mathrm{ppm}$, where the highest antioxidant level found in treatments E of $23.62 \%$ (50\% kolang kaling : $50 \%$ jackfruit) and the lowest antioxidant level found in treatment A of $14.89 \%$ (90\% kolang kaling : 10\% jackfruit). The higher the mixture level of jackfruit in fruit leather, the higher the level of antioxidant, this presumably caused by the presence of a carotenoid compound as beta carotene which contained in jackfruit. Betacarotene is a compound that classed as a carotenoid, which uses as a precursor of vitamin A, antioxidant, increase the immunity of the body, and change the metabolism of cancer (Arab, et al., 2001$)^{\mathbf{2 4}}$

\section{Conclusion and Suggestion:-}

\section{Conclusion:-}

A different mixture of kolang kaling and jackfruit had a significant effect on water content and ash content of fruit leather. But no significant effect on antioxidant activity and beta-carotene content

\section{Suggestions:-}

Based on research conducted authors suggest for further research to analyze the shelf life and packaging of fruit leather mixture kolang kaling and jackfruit. Also for further research to use spreading tools to simplify the flattening process in making the fruit leather so that the thickness of fruit leather will be prevalent. 


\section{References:-}

1. Raab, C. and Oehler, N. 2000. Making Dried Fruit Leather.Extention Food and Nutrition Specialist. Oregon State University. Oregon. US.

2. Nurlaely, E. 2002. Pemanfaatan Buah Jambu Mete Untuk Pembuatan Fruit Leather Kajian Dari Buah Pencampur. Jurusan Teknologi Hasil Pertanian. Universitas Brawijaya. Malang.

3. Winarti, S. 2008. Pembuatan Buah Mengkudu (Morinda citrifolia) dan Kelopak Bunga Rosella (Hibiscus sabdariffa) untuk pembuatan fruit leather. Agritech. Vol (1) 28: 22-27

4. Ratima, S. 2014. Khasiat Tersembunyi Kolang Kaling. Tabloid Sinar Tani. Jawa Barat. http:www.tabloidsinartani.com/content/read/khasiattersembunyikolang-kaling/. [January $5^{\mathrm{Th}}, 2016$ )

5. Ipi. 2014. Manfaat Buah Kolang Kaling Untuk Kesehatan. Bulletin Pemerintah Kota PagarAlam. http://pagaralamkota.go.id [May $\left.22^{\text {nd }}, 2014\right]$.

6. Kooiman, P. 1971. Structures Of The Galactomannans from Seed Of Annona mucirata, Arenga saccharifera, Cocos nucifera, Convolvulus tricolor And Sophora japonica. [Abstract]. Carbon, Res. University of The Philippines Manila, 2013. Http; // HerbxPh/Index, Php/Article. [January $8^{\text {th }}, 2015$ ].

7. Fardiaz , D. 1989. Hidrokoloid .Laboratorium Kimia dan Biokimia Pangan. Pusat Antar Universitas Pangan dan Gizi. Institut Pertanian Bogor. Bogor.

8. Anggadireja, J. T, Zatnika, A, Purwoto, and S. Istini. 2006. Rumput laut: Pembudidayaaan. Pengolahan Dan Pemasaran Komoditas Perikanan Potensial. Penebar Swadaya. Jakarta. 2006.

9. Widyastuti.1993. Jackfruit dan Cempedak. Penebar Swadaya. Jakarta.

10. Yenrina, R., K. Sayuti. and R.T. Maharani.2015. Acceptability and Antioxidant Activity of Vegetable Leather of Soursop Leaves (Annona muricata) and Seaweed (Escheumacottoni) with Addition of Strawberries (Fragaria vesca L). Pakistan Journal of Nutrition. 14 (8): 496-502.

11. Yenrina, R., Juliana and D. Rasjmida. 2011. Metode Analisa Bahan Pangan. Unand Press. Universitas Andalas. Padang.

12. Nielsen, S. 1995. Introduction to The Chemical Analysis Of Food. Chanman and Hall. New York.

13. Huang, Yu-Ching, Yung-Ho and Shao, Yi-Yuan. 2005. Effect of Genotype and Treatment on the Antioxidant Activity of Sweet Potato in Taiwan. Food Chemistry, 2005.98 :529-538

14. Winarno, F. G. 2004. Kimia Pangan Dan Gizi. PT Gramedia Pustaka Utama. Jakarta.

15. DepKes RI. 2009. Kandungan Nutrisi Biji Jackfruit. Departemen Kesehatan Indonesia. Jakarta. 2009.

16. Hui, Y. H,. 2006. Handbook Of Food Science, Technology And Engineering Volume I. CRC press, USA.

17. USDA (United State Department Of Agriculture). 2009.Jackfruit. Raw.https://ndb.nal.usda.gov/ndb/foods/show/jackfruit.[March $\left.15^{\text {th }}, 2016\right]$.

18. Muchtadi T R. 1981. Pengaruh Penyimpanan Beku Terhadap Mutu Daging Buah Jackfruit. Fakultas Teknologi Pertanian. Institut Pertanian Bogor.

19. DeMan, J. M. 1997. Kimia pangan. Penerbit ITB. Bandung,

20. Afrianti, L H. 2010. Pengawetan Makanan Alami dan Sintetis. Alfabeta. Bandung.

21. Almatsier, S. 2009. Prinsip Dasar Ilmu Gizi. Gramedia. Jakarta.

22. Astawan, M. Antioksidan Tingkatkan Pamor Bengkoang. 2009. http://cyberwoman.cbn.net.id [December $\left.2^{\text {nd }}, 2015\right]$.

23. Sayuti. K and R. Yenrina. 2015. Antioksidan Alami dan Sintetik. Unand Press. Universitas Andalas. Padang.

24. Arab, L., S. Steck-Scoot and P. Bowen. 2001. Participation Of Lycopen And Beta-Carotene In Carcinogenesis: Defender, Aggresors, Or Passive Bystanders, Epidemologi Reviews, Vol. 23 (2): 221-229 